\title{
PHYTOREMEDIATION OF SEWAGE SLUDGE IN SOILS CONTAMINATED WITH HEAVY METALS
}

CORNELIUS O. AWALLA

\begin{abstract}
The main source of heavy metals in most soils is sewage sludge. Naturally, the heavy metals in soils are transported to vegetations and cultivated crops. These pollutants need to be either reduced or eliminated in the soil to remediate the effects to man, animals, plants, soils, and groundwater. Hence, Jatropha curcas seedlings were planted on six different media to determine the concentration of heavy metals. Thereafter, it was discovered that Jatropha curcas plants through their roots, stems and leaves metabolism, morphology and mechanisms can reduce the concentration of heavy metals like Zinc, Lead, Chromium, Cadmium, and Copper etc effectively from any medium containing $100 \%$ sewage sludge. Thus, it was discovered that Jatropha curcas plant is suitable as a phytoremediator of heavy metals in soils.
\end{abstract}

KEYWORDS: Heavy metal, phytoremediation, sewage sludge, metabolism, morphology.

\section{INTRODUCTION}

Worldwide, heavy metals cause pollution which is a serious environmental crises. Heavy metals exist in soils as free metal ions, soluble metal complexes, exchangeable metal ions, organically bound metals, precipitated or insoluble compounds like oxides, carbonates and hydroxides. They cause soil pollution by the repeated increase daily or weekly application of sewage sludge, municipal wastes, animals slurries, activities of mining, smelting and agricultural industries, and also impurities in fertilizers, herbicides, germicides and decomposition and burning of fossil fuels.

The environmental pollutants are different types of solvents like trichloroethylene (TCE), atrazine, trinitroluene (TNT), oil, gasoline, benzene, polycyclic aromatic hydrocarbons (PAHs), and fuel additives (Hong et al 2001). These are inorganic pollutants which include plant phosphate, $\mathrm{Cr}, \mathrm{Fe}, \mathrm{Mn}, \mathrm{Mg}, \mathrm{Ni}, \mathrm{Zn}$, and $\mathrm{Cu}$, and non-essential elements like $\mathrm{As}, \mathrm{Cd}$, and $\mathrm{Hg}$ (Batiha, et al, 2008)

Jatropha is a great plant for restoring nutrients in the soil, and has the ability to turn poorly-over used soil into great purposeful agricultural productivity and yields (Awalla, 2013). However, organic and inorganic pollutants greatly impact human health and ecological biodiversity systems. Harmful inorganic pollutants in the soil like heavy metals can be eliminated through phytoremediation mechanisms and techniques.

The sources of sewage sludge are the solid waste products from wastes treatment, mining residues and agricultural wastes. Heavy metals like cadmium, manganese and zinc in the soil and plant tissues increase after sewage sludge had been applied to them. This phenomenon contributes great pollution of the waterways (Jones and Johnson, 1989).

The most common heavy metals in soils and plants are Lead PB, Cadmium (Cd), Chromium (Cr), Mercury (Hg), Zinc( $\mathrm{Zn})$ and

Cornelius O. Awalla, Department of Geology and Mining, Faculty of Applied Natural Sciences, Enugu State University of Science and Technology Enugu, Enugu State, Nigeria. 
Copper (Cu) (Kabata-Pendias and Pendias, 2001). All of them cause health problems (Yadav et al, 2009) especially mercury which is highly toxic if breathed or ingested. Mercury is residual in the environment, showing biological accumulation in all aquatic organisms, especially in fish and shellfish. Chronic exposure to airborne mercury can have serious effects on the central nervous system (CNS).

Thus, phytoremediation is the use of green vegetables for the in-situ or ex-situ treatment of contaminated soils, sediments and polluted water and to detoxify inorganic and organic metals (Salt, et al, 1995; Damian, 2007; Afkar et al, 2010). Phytoremediation is a green technology which has been used to facilitate the removal of heavy metals from soils and plants. It is very important to clean up soils.

JATROPHA CURCAS PLANTS AS A CHOICE.

- It has promising characteristics like robust nature, rapid gestation period, excessive recovery and survives all seasons. Jatropha curcas plant is suitable as a phytoremediator that removes hydrocarbons from contaminated soil (Agamuthu, et al, 2010), and also removes Cadmium,(Cd) and Lead, $(\mathrm{Pb})$ (Chehregani and Malayeri, 2007).

- The research was carried out at the Nigerian Institute for Oil Palm Research (NIFOR) Benin , Delta State of Nigeria.

- The humid rainforest climate with perennial streams and rivers and lowland shales encourage luxurious grasses trees like cashew, mango, palm, raffia, banana, bamboos etc

- Contaminants attenuation mechanisms by phytoremediation are very complex, and thus should be limited to the direct metabolism of contaminants by plants, but other indirect attenuation mechanisms like the metabolism of contaminants by plant-associated microbes and plants-induced changes in the contaminated environment, transport of contaminants into the plant system is highly dominated by up-taking of the liquids by the roots of the plants. (Shimp et al, 1993; Macek et al, 1998)

Phytoextraction takes effect where heavy metals, radionuclide and some organic compounds are resistant to plant metabolism. It can also occur where uptake and translocation of these compounds in the soils by plants tissues are in recoverable state of existence. These plants are hyperacumulators of metals. However, when the plants are matured, harvested and disposed, they are processed by incineration and composted for recycling in case of organic pollutants.

Bioavailable contaminants like PAHs and NACs after incineration of plants can be decontaminated effectively by careful disposal in a hazardous waste landfill. The non- availability of other pollutants can be bioavailable by adding chemical additives like bio-surfactant, and EDTA to the soil (Maier et al, 2001).

Phytodegradation/ phytotransformation occurs when contaminants are taken up from soil and/ or water by the plant roots, then metabolized into less toxic and non-toxic compounds within the plant tissues through the actions of substances produced by the plants (Shimp et al, 1993). Herbicide phytodegradation extends to cell cultures of non-crops species including hybrid poplar trees. The metabolic processes in phytodegradation are analogous to human metabolism of xenobiotic chemical. Hydrophobic organic chemicals are not very efficient for phytoremediation, because these contaminants cannot be easily translocated within the plants as they are either bound strongly to the surface of the roots or are not absorbed by roots and thus not actively transported through plant membranes (Batiha et al, 2008)

Phytovolatilization occurs when volatile chemicals/contaminants like trichloroethylene (TCE), polychlorinated biphenyls (PCBs) and total petroleum hydrocarbons are released into the atmosphere through plant transpiration. Some inorganic pollutants that are very difficult to control at the subsurface environment react rapidly in the atmosphere with hydroxyl radicals.

* The transfer of contaminants from soil/groundwater to atmosphere may not be as desirable as in-situ degradation, but better than long time exposure of contaminants in soil to reduce ground water contamination.

Rhizodegradation occurs when the contaminants are transformed by microbes in the rhizosphere, i.e. microberich zone within the vascular root- system of the plant. The plant roots manipulate 
the soil redox characteristics, organic matter and moisture content. Here deeprooted plants remove petroleum hydrocarbons from soil. Microbial activity causes removal of polycyclic aromatic hydrocarbons (PAHs) which is associated with chemical oxidation, bioaccumulation and microbial transformation. Microbial activity is higher in the rhizosphere due to readily availability of biodegradable substrates that exude front the plant (fig.1)

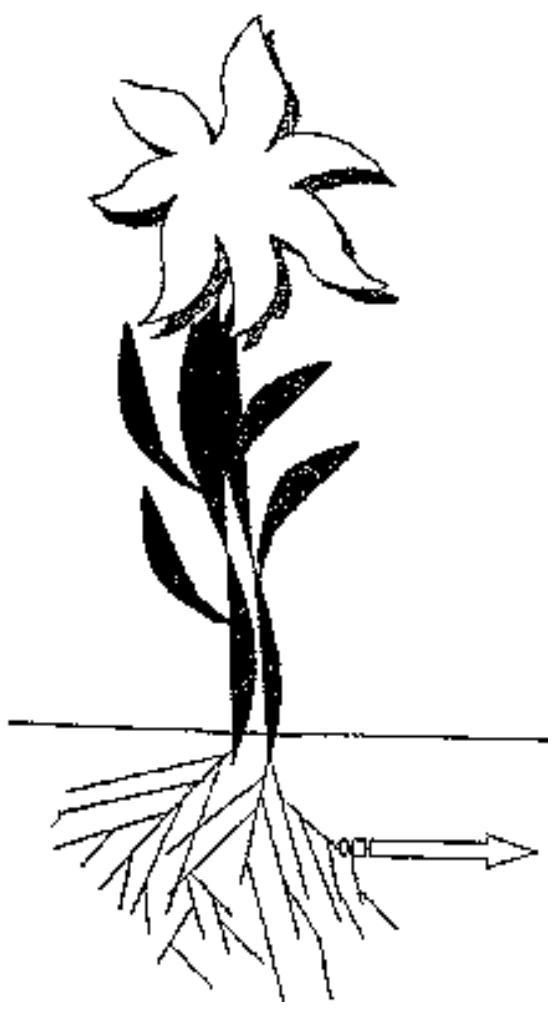

Xenobiotic and organic contaminants<smiles>C1CCC1</smiles>

RHIZOSPHERE

Microorganisms (Algae, Bacteria, Fungi) and plant carbon compounds (exudates, mucilage, dead cells)<smiles>C1=CC1</smiles>

Activation, Detoxification, Mineralization

Fig.1. Schematic diagram showing Rhizodegradation of toxic contaminants by rhizospheric microorganisms 


\section{${ }^{*}$ Advantages of Jatropha curcas plant}

Jatroph curcas tree is drought resistant and relatively easy to propagate. It cannot be damaged by any adverse environmental conditions. It is very environmental friendly and capable of stabilizing sand dunes. It is highly adaptable to wind, all soil-types, desertification and deforestation. It repels insects and naturally animals cannot browse it. It is all weather friendly and lives more than 50years producing fruits all the time.

In addition Jatropha tree produce oil from its seeds which is used to lubricate farm equipment and machinery, and also to soften hides when ropes and whips are produced in Zimbabwe. Jatropha oil used in lanterns for light because the oil burns with smoke-free flame. The jatropha is used as live fence to protect crops gardens/farmlands (and irrigated areas) from damage by livestock. Jatropha seeds produce good detergents and soaps manufacture in the ratio of 5 parts oil: 8 parts water: 2 parts caustic soda.

The plant is used for land reclamation and soil conservation works, because it has favourable root systems that easily bind soil particles and aggregates together to reduce soil erosion. Therefore, it can be planted on marginal land, paddocks (i.e. a small field where horses are kept), hilly slopes, valleys and gullies. The roots grow close to soil surface which anchor soils like miniature dykes or earthen. It slows runoff and allows more water to infiltrate and percolate deep into the root-zones to aid and boost large agricultural harvests.

Jatropha oil cures cardiac problems ,rheumatism (i.e. pain in joints) and back pains, or aches. Its nut sap is used to treat bleeding. Concoction of Jatropha leaves is used as antiseptic after birth. Its roots cure snake bites and its seeds are used to reduce constipation. The plant treats skin diseases and also remedies sores on domestic livestock. Its latex with alkaloids, namely Jatrophine, Jatrophen, Jatrophore and curtain are anti-carcinogenic. Jatropha latex remedies the effects of burns, eczema, inflammation, paralysis and yellow fever.

Jatropha plants around homesteads prevent entry of snakes and repels evil spirits, and used to settle disputes brought before traditional leaders, e.g. if an accused person drinks the concoctions and did not vomit, he/ she is presumed guilty. It is perfect in bees keeping.

Jatropha plant is used to manufacture biogas and fertilizers. It is used as green manure and fire wood. Farmers must be careful of phytotoxicity expressed as reduced germination. Organic fertilizers can substitute inorganic fertilizers, especially for small farmers that cannot afford inorganic fertilizers. Therefore, Jatropha cake used as organic fertilizers must be allowed total decomposition before application in farmlands. It produces insecticides, herbicides, fungicides and veterinary chemicals.

Jatropha stem/root extracts control Helicoverpa armigera, Aphis gossypii, phthorimaea operculela, sitophilus zeamays and empoasca spp. Jatropha leaf extracts control selerotium and schistoseme vector snails, and also tick- related diseases and kills bilharzias snails. Jatropha seed husks are used as combustible fuel, and the seed cake in biogas production and folder i.e. non-toxic varieties (Agamuthu et al 2010, Batiha et al 2008, Chehregani and malayeri, 2007).

\section{EXPERIMENTS}

The experiment was performed on $6^{\text {th }}$ May, 2011 at the Nigerian Institute For Oil-palm Research (NIFOR), Benin, Delta State of Nigeria. The seeds of matured Jatropha curcas plants were collected and planted in polythene bags (16. $0 x 16 \mathrm{~cm})$ in the ratio of soils: organic matters: river sand. After one month, the seedling were transplanted to plastic pots of $32 \mathrm{~cm}$ height, $106 \mathrm{~cm}$ upper diameter and $69 \mathrm{~cm}$ low diameter which were filled with soil and sewage sludge. Using Completely Randonized Lesign (CRD), each pot was labeled according to its composition, e.g. $\mathrm{T}_{0}\left(100 \%\right.$ soil), $\mathrm{T}_{1}(80 \%$ soil and $20 \%$ sewage sludge $), \mathrm{T}_{2}(60 \%$ soil and $40 \%$ sewage sludge), $\mathrm{T}_{3}$ (40\% soil and $60 \%$ sewage sludge), $\mathrm{T}_{4}(20 \%$ soil and $80 \%$ sewage sludge $)$, and $T_{5}(100 \%$ sewage sludge). The height and basal diameter of each jatropha plant is measured with venier caliper and diameter tape. Inductively Coupled Plasma- Mass Satrometer (ICP-MS) was used to analyze the sample solutions of heavy metals concentration (Sahoo, Das and Mukherjee, 2009), while 
hydrochloric acid $(\mathrm{HCl})$ and nitric acid $\left(\mathrm{HNO}_{3}\right)$ were used as extractants. Local carbon was determined with a loss on ignition analyzer and $5 \mathrm{~g}$ of air dried soil at $500^{\circ} \mathrm{C}$. ICP-MS can scan all elements in a sample simultaneously. This allows for more rapid sample processing and acceptable results output. However, atomic absorption spectroscopy (AAS) can only measure a single element at a time.

\section{OBSERVATIONS}

After three to six months (i.e. 12 to 24 weeks), it was observed that the Jotropha curcas plant in $\mathrm{T}_{3}$ medium ( $40 \%$ soil and $60 \%$ sewage sludge) had the tallest height $(8.59 \mathrm{~cm})$ while $\mathrm{T}_{2}$ $(60 \%$ soil and $40 \%$ sewage sludge) had the shortest height $(6.75 \mathrm{~cm}) ; \mathrm{T}_{4}(20 \%$ soil and $80 \%$ sewage sludge) had largest basal diameter $(3.95 \mathrm{~cm})$ compared to the plant in $100 \%$ soil medium $\left(T_{0}\right)$, but $100 \%$ soil medium allows highest number of leaves, followed by $T_{1}$ and $T_{2}$. Every week the number of leaves increased, except plants in $T_{4}$ and $T_{5}$ with less leaves. The highest total carbon was found in $T_{5}(0.25 \mathrm{~g} / \mathrm{kg})$ followed by $T_{4}$. In all $T_{1}-T_{5}$, soil $P^{H}$ before planting was 6.5 due to the presence of heavy metals in the soil which made the soil to be slightly acidic and after harvesting $\mathrm{P}^{\mathrm{H}}$ tended to alkalinity 8.0 due to absorption of soil nutrients by plant roots, but according to Sally, 2000 the control treatment has $p^{\mathrm{H}} 7.5$ which is the test for $p^{\mathrm{H}}$ level of the soil. The $\mathrm{P}^{\mathrm{H}}$ of soils stored in air-tight plastic bags is generally affected as result of microbial activity eg. the occurrence of moulds (Faniran and Areola, 1978).

\section{RESULTS}

Jatropha curcas plant can reduce heavy metals like $\mathrm{Zn}, \mathrm{Pb}, \mathrm{Cr}$ and $\mathrm{Cu}$ in $\mathrm{T}_{5}(100 \%$ sewage sludge), e.g. $\mathrm{Zn}$, content of the sewage sludge was $29.55 \mathrm{mg} / \mathrm{kg}$ in roots, $6.21 \mathrm{mg} / \mathrm{kg}$ in stem and $3.15 \mathrm{mg} / \mathrm{kg}$ in leaves (Tabs 1-3). This is same for $\mathrm{Pb}, \mathrm{Cr}$, $\mathrm{Cd}$ and $\mathrm{Cu}$.

After the $3-6$ months of planting (Tab.3), Jatropha curcas plant has the highest accumulation of $\mathrm{Zn}(29.55 \mathrm{mg} / \mathrm{kg})$ in the roots of $T_{5}$, (100\% sewage sludge) than in the stem and leaves (Tab .1), but the highest accumulation of $\mathrm{Pb}(4.65 \mathrm{mg} / \mathrm{kg})$ was in the leaves of $\mathrm{T}_{4}(20 \%$ soil and $\quad 80 \%$ sewage sludge).

Table 1: Heavy metal concentration in leaves of Jatropha curcas plant after $3-6$ months $(\mathrm{mg} / \mathrm{kg})$.

$\begin{array}{llllll}\text { Medium } & \text { Zinc } & \text { Lead } & \text { Chromium } & \text { Copper } & \text { Cadmium } \\ \mathrm{T}_{0} & 0.45 & 0.06 & 0.01 & 0.06 & \text { bdl } \\ \mathrm{T}_{1} & 1.37 & 1.35 & 0.02 & 0.09 & \text { bdl } \\ \mathrm{T}_{2} & 5.09 & 3.38 & 0.03 & 0.09 & \text { bdl } \\ \mathrm{T}_{3} & 1.98 & 4.15 & 0.03 & 0.05 & \text { bdl } \\ \mathrm{T}_{4} & 4.35 & 4.65 & 0.04 & 0.09 & \text { bdl } \\ \mathrm{T}_{5} & 3.15 & 2.55 & 0.02 & 0.08 & \text { bdl }\end{array}$

(bdl means below detection limit)

Table 2: Heavy metal concentration in stem of Jatropha curcas plant after $3-6$ months $(\mathrm{mg} / \mathrm{kg})$.

$\begin{array}{llllll}\text { Medium } & \text { Zinc } & \mathrm{Pb} & \mathrm{Cr} & \mathrm{Cu} & \mathrm{Cd} \\ \mathrm{T}_{0} & 1.13 & \text { bdl } & 0.18 & 0.13 & \text { bdl } \\ \mathrm{T}_{1} & 4.94 & \text { bdl } & 0.33 & 0.35 & \text { bdl } \\ \mathrm{T}_{2} & 8.00 & \text { bdl } & 0.17 & 0.23 & \text { bdl } \\ \mathrm{T}_{3} & 9.18 & \text { bdl } & 0.20 & 0.10 & \text { bdl } \\ \mathrm{T}_{4} & 5.02 & \text { bdl } & 0.15 & 0.15 & \text { bdl } \\ \mathrm{T}_{5} & 6.21 & \text { bdl } & 0.18 & 0.11 & \text { bdl }\end{array}$

(bdl means below detection limit) 
Table 3: Heavy metal concentration in roots of Jatropha curcas Plant after 3 - 6 months $(\mathrm{mg} / \mathrm{kg})$

$\begin{array}{llllll}\text { Medium } & \text { Zinc } & \mathrm{Pb} & \mathrm{Cr} & \mathrm{Cu} & \mathrm{Cd} \\ \mathrm{T}_{0} & 1.05 & \mathrm{bdl} & 0.22 & 0.21 & 0.00 \\ \mathrm{~T}_{1} & 6.52 & \mathrm{bdl} & 0.18 & 0.17 & 3.18 \\ \mathrm{~T}_{2} & 15.87 & \mathrm{bdl} & 0.15 & 0.15 & 8.39 \\ \mathrm{~T}_{3} & 13.62 & \text { bdl } & 0.25 & 0.23 & 2.11 \\ \mathrm{~T}_{4} & 12.45 & \text { bdl } & 0.47 & 0.47 & 5.20 \\ \mathrm{~T}_{5} & 29.55 & \text { bdl } & 0.35 & 0.35 & 8.29\end{array}$

(bdl means below detection limit)

\begin{abstract}
ANALYSES
For the accumulation of heavy metals like zinc, lead, chromium, copper and cadmium in the leaves, stem and roots of Jatropha curcas plants, within three to six months of planting, zinc is accumulated in the leaves of medium $\mathrm{T}_{2}(60 \%$ soil and $40 \%$ sewage sludge) with $5.09 \mathrm{mg} / \mathrm{kg}$, and lead, $4.65 \mathrm{mg} / \mathrm{kg}$ in $\mathrm{T}_{4}(20 \%$ soil and $80 \%$ sewage sludge).

In the stem, zinc is accumulated $9.18 \mathrm{mg} / \mathrm{kg}$ in medium $\mathrm{T}_{3}(40 \%$ soil and $60 \%$ sewage sludge) and $8.00 \mathrm{mg} / \mathrm{kg}$ in medium $\mathrm{T}_{2}$ ( $60 \%$ soil and $40 \%$ sewage sludge). However, zinc is accumulated $29.55 \mathrm{mg} / \mathrm{kg}$ in the roots of medium $\mathrm{T}_{5} \quad(100 \%$ sewage sludge), and in $\mathrm{T}_{2} 15.87 \mathrm{mg} / \mathrm{kg}(60 \%$ soil and $40 \%$ sewage sludge).
\end{abstract}

\section{RECOMMENDATIONS}

Jatropha curcas plant as an environmental-frendly plant survives in all weather conditions, that is both rainy and dry seasons. It is therefore recommended as an effective means and method of phytoremediation of heavy metals and other contaminants in soil and groundwater.

The effective characteristics of the Jatropha curcas plant depend mainly on the accumulative capacity of its leaves, stems and roots. Thus, due to its effective accumulative capacity and metabolism of the contaminants,jatropha curcas plant has been recommended worldwide as all-weather environmental friendly and an effective phytoremediator.

Therefore, with the availability of Jatropha curcas plant around residential houses, industries, schools, offices, hospitals, markets and other public buildings in both rural areas and developed cities, the effects of sewage sludge in soils and groundwater will be drastically reduced and subsequently remediated.

\section{CONCLUSION}

Therefore, $T_{2}(60 \%$ soil and $40 \%$ sewage sludge) medium with highest number of leaves is ideal for the phytoremediation of most heavy metals like zinc, lead, chromium, copper and cadmium. However, the accumulations of these heavy metals occur mainly in the leaves, stems and roots of Jatropha curcas plant. Jatropha curcas plant has been accepted worldwide as an environmental friendly plant and most valuable phytoremediator controller of groundwater and soil contamination.

The highest $\mathrm{Zn}$ accumulation, $29.55 \mathrm{mg}$. $\mathrm{kg}$ was in roots of $T_{5}$ with $100 \%$ sewage sludge, than leaves and stem. $\mathrm{Pb}$ accumulation, $4.65 \mathrm{mg} / \mathrm{kg}$ was higher in leaves than stem and roots of $\mathrm{T}_{4}$ with $20 \%$ soil and $80 \%$ sewage sludge. However, Jatropha plant is not a good accumulator of lead $(\mathrm{Pb})$, because only small amount is absorbed due to less adaptability and small strength of absorption strength of lead $(\mathrm{Pb})$ into the plant tissues. More Chromium (Cr), Copper $(\mathrm{Cu})$, and Cadmium (Cd) were accumulated in roots than in stems and in leaves (Tabs 1,2,3).

Either soil or sewage sludge that contains high amount of zinc $(\mathrm{Zn})$ retards plant growth. Jatropha curcas plant growth very slowly where sewage sludge is $100 \%\left(T_{5}\right)$ due to high zinc content. Generally, plant growth can be retarded due to low soil nutrients (especially N.P.K) and low water holding capacities, high toxic substances, high salinity and excess acidity and alkalinity in soils. 


\section{REFERENCES}

Afkar, E., Ababna H and Fathi, A. A., 2010. Toxicology response of the green algae chlorella vulgaris, to some heavy metals Am. J. Environs. Sci. 6, $230-237$.

Agamuthu, P., Abioye, O. P and Aziz, A. A., 2010. Phytoremediation of soil contaminated with used lubricating oil using Jatropha curcas. Journ Hazard Mater., 179, 891 894.

Awalla, C. O. C., 2013. Global Environmental Sustainability. Goodseed Pub. Nsukka Enugu State, Nigeria. 158.

Batiha, M. A., Kadhum, A. A. H., Mohamad, A. B., Takriff, M. S and Fiscal, Z., 2008. MAM - an equivalence - based dynamic mass balance model for the fate of non-volatile organic chemicals in the agricultural environment. Am. J. eng. Applied Sci. 1, $252-259$

Chehregani, A and Malayeri, B. E., 2007. Removal of heavy metals by native accumulator plants. Int. J.Agric. Biol, 9, $462-465$.

Damian, $\mathrm{F}$ and Damian, G., 2007. Detoxification of heavy metals contaminated soils. Am. J. Enu. Sc., 3, $193-198$.

Faniran, F and Areola, O., 1978. Essentials of Soil Study. With special reference to tropical areas. Heinemann Pub, London. 278.

Hong, M. S., Farmayan, I. J., Dortch, C. Y and Chiangand, S. P., 2001. Phytoremediation of MTBE from a groundwater plume. Environmental Sc.Tech., 35, 1231 1239.

Jones, K. C and Johnson, A. E., 1989. Cadmium in cereal grain and herbage from longterm experimental post at Rothamsted, UK. Enu. Pollut., 57, 199 - 316.

Kabata - Pendias, A and Pendias, H., 2001. Trace elements in the soil and plants. CRC Press, Boca Raton, $3^{\text {rd }}$ Ed. $413 p$.
Macek, T., Mackova, M., Kucerova, P., Burkhard, J., Trisk, J and Demnerova, K., 2000. Plant tissue cultures in model studies of transformation of polychlorinated biphenyls. Chem. Papers 52, $599-600$.

Maier, R. M., Neilson, J. W., Artiola, J. F., Jordan, F. L., Glenn, E. P and Descher, S. M, 2001. Remediation of metal-contaminated soil and sludge using biosurfactant technology. Inter. J. Occup. Med. Env. Health 14, $241-248$.

Sahoo, B. K., Das., B. P and Dukherjee, D., 2009. Kelativistic coupled. Cluster studies of ionization potentials, lifetimes and polarizabilities in singly ionized calcium. Phys. Rev. A.; 79, 1 - 9.

Sally, W., 2000. Oxford Advanced Learner's Dictionary, $6^{\text {th }}$ Edition Oxford University Press, Uk. 1422pp.

Salt, D. E., Blaylock. M., Kumar; N. P. Dushenkov, V. and Ensley, B. D., 1995: Phytoremediation: A novel strategy for the removal of toxic metals from the environment using plants. Biotechnology, $13,468-474$.

Shimp, J. F., Tracy, J. C., Daviz, L. C., lee, E., huang W., Ericknon, L. E and Schnoor, J. L., 1993: Beneficial effects of plants in the remediation of soil and groundwater contaminated with organic materials. Crit. Rev. Env. Sci. Tech. 23, $41-77$.

Yadav, S. K., Juwarkar, A. A., Kamur, G. P., Thawale, P. R and Singh, S. K., 2009. Bioaccumulation and Phyto-translocation of arsenic chromium, and zinc by Jatropha curcas L.: Impact of diary sludge and biofertilizer. Bioresour. Tech., $100,4616-4622$ 